\title{
A PÁLINKA ELŐÁLLÍTÁSÁVAL KAPCSOLATOS JOGSZABÁLYVÁLTOZÁSOK (2010) - ELŐÁLLÍTÁSI FELTÉTELEK, ADÓZÁSI KÖTELEZETTSÉGEK - HATÁSAINAK VIZSGÁLATA A GYAKORLATBAN
}

\author{
Zsótér Brigitta - Molnár Anikó
}

\begin{abstract}
Absztrakt: Kutatásunk témája a pálinka előállítás terén a 2010-ben bevezetett jogszabályváltozások - elöállítási jogosultság további engedményezése, jövedéki termékekre vonatkozó adójogszabályok változása - hatásainak vizsgálata a gyakorlatban. Kérdőives vizsgálatot végeztünk a bérfözetökkel, hogyan vélekednek a meghozott rendeletekröl, valamint mennyiben befolyásolta ez fözetői szokásukat. A primer kutatáshoz tartozik 5 interjú, amit a témában szakmailag jártasabb személyekkel készitettünk. A bér- és kereskedelmi fözdék üzemeltetöi, illetve a magánfözők kifejtették véleményüket, és megosztották velünk az utóbbi 4 év tapasztalatait. A 43 hektoliterfok mértékig bevezetett 0 forintos adófizetési kötelezettség pozitiv hatással volt a bérfözésre. A magánfözés engedélyezése megosztotta a bérfözetök véleményét, viszont a fözdék üzemeltetöi rámutattak a bejelentési kötelezettség hiányára, ami negatív következményeket vonhat maga után.
\end{abstract}

\begin{abstract}
The subject of our research is the examination of effects of changes in law, introduced in 2010 , in the field of the distillation of 'pálinka', like further assignment of distillation rights and changes in tax laws concerning products subject to excise duty. We have carried out questionnaire surveys with leased distillers on what they think of the orders and also on how much it affected their distillating habits. The primary research includes 5 interviews made with people who are professionally more competent in this subject. The owners and operators of the leased and commercial distilleries together with the private distillers expressed their opinions and shared their experiences about the last four years with us. The tax obligation of 0 forint introduced to 43 volume percentage has a good effect on the leased distillation. Permition of private distillation has divided the opinion of the leased distillers, and the owners of distilleries underlined the lack of the duty of registration which may have negative consequences.
\end{abstract}

Kulcsszavak: pálinka, hektoliterfok, bér- és kereskedelmi fözdék

Keywords: pảlinka (brandy), volume percentage, leased and commercial distilleries

\section{Bevezetés}

Kutatásunk témája a pálinka előállításával kapcsolatos jogszabályváltozások hatásai a gyakorlatban, amelyben az előállitási feltételeket, valamint az adózási kötelezettségeket vizsgáltuk meg.

A felmérés kiterjed a bérfözetök véleményére, ezen kívül a magánfözetök meglátására a korábban meghozott törvényröl, valamint rendeletről (2010). Mindemellett a szakmában jártas személyek - bér- és kereskedelmi szeszfözde üzemeltető - véleményét is felmértük a témával kapcsolatban.

A következö hipotéziseket vizsgáltuk:

1.) A 43 hlf (hektoliterfok) elöállításának mértékéig bevezetett 0 forint adófizetési kötelézettség megnövelte a pálinkafözés iránti kedvet a bérszeszfözdékben. 
2.) A jogszabályváltozások liberalizálását követően elterjedt a legális otthoni pálinkaföző készülékek száma.

3.) A szakmai tudás, a magas költségek és a nem megfelelö minőségü pálinka miatt az otthonfözetők kedve alábbhagyott.

4.) A bérfözetők nem fözetnék ki cefréjüket, ha az meghaladná a 43 hlf-ot, és utána adót kellene fizetni.

5.) A vizsgált területen, a bérfözetök életkorát tekintve, leginkább az idősebb, 45 év feletti személyek veszik igénybe a bérszeszfözde szolgáltatását.

A kutatásunk célja, hogy saját vizsgálat során ezeket a hipotéziseket alátámasszuk, vagy elvessük.

\section{Szakirodalom feldolgozása}

Igen sok szakirodalmi munka található a témával kapcsolatban. Ezek közül kiemelnénk Balázs $(1998,2004)$ a magyar pálinkával, valamint ennek elóállításával foglalkozó munkáit. A házi pálinkafözéssel kapcsolatos ismeretekhez nélkülözhetetlen Békési és Csarnai (2010) könyvének a tanulmányozása. A gyümölcspálinka-fözésről Szabó (2012) munkájában olvashatunk részletesen.

Legelöször a pálinka fogalmát tisztáznánk. A pálinka semmilyen adalékanyagot (cukor, méz) nem tartalmazó, 100\%-ban gyümölcsböl, erjesztéssel készült gyümölcscefre lepárlásával nyert párlat. Az Európai Unió területén kizárólag (export esetén is) csak Magyarországon termett és termelt gyümölcs az alapanyaga, melynek alkoholfoka minimum $37,5 \% \mathrm{~V} / \mathrm{V}$. A pálinka nevet, kizárólag Magyarország, a barackpálinka nevet még 4 osztrák tartomány használhatja (Jónás, 2006; Panyik, 2013).

$\mathrm{Az}$ alkoholos erjedés már ősidők óta ismert. A lepárlás folyamata viszont csak az ezredforduló után terjedt el a világban. A XVI. század végéig a desztillációval előállitott szeszt csak gyógyszerként alkalmazták, ami bizonyítja az „aqua vitae”, azaz az „élet vize" elnevezését a szesznek. Földrajzi fekvéstöl függően nevezték még „aquavit”-nek, illetve „lebenswasser”-nek. A párlat XV-XVI. század végére kereskedelmi cikk lett. 1722-ben jelent meg olyan dokumentum, amelyben a „pálinka” megnevezést először használták. Erre azért volt szükség, hogy megkülönböztessék a gabonából készült párlatokat, a borból készült párlatoktól. A gyümölcspálinka néhány évvel később terjedt el. Magyarországon a szeszadót 1850-ben vezették be, ettől az időponttól beszélünk az elóállitással kapcsolatban felmerülö, az állam javára megfizetendő adónemről (Békési és Pándi, 2005; Panyik, 2013).

A következő jelentős változást a szeszmérő gépek kötelezö gyakorlati alkalmazásának bevetése jelentette 1924-től. A gépek azt a célt szolgálták, hogy kimutassák a rajtuk átfolyt szesz mennyiségét és erősségét, ezáltal mérhetővé és ellenörizhetövé tették az elöállitott mennyiséget. További fordulatot jelentett a II. világháború utáni államosítások sorozata. Az 1949 után bevezetett rendeletek kárt okoztak a termelőknek és az állami iparnak egyaránt, ugyanis a fỏzdék által 
termelési időszakonként elöállítható pálinka mennyiségét, és a kifözhető mennyiséget az állam szigorúan meghatározta (Békési és Pándi, 2005).

A pálinka elöállitás terén a legnagyobb áttörést az 1982-es elöállítási jogosultságra vonatkozó rendelet jelentette. A rendelet értelmében „Magánszemély - pálinka bérfözés céljára - legfeljebb 500 liter fözőüst kapacitású fözdét létesíthet." Ennek következtében megkezdték a termelést az állami szeszfőzdék mellett a magántulajdonban lévő bérszeszfözdék is (Békési és Pándi, 2005). Itt meg kell jegyeznünk, hogy mindez kihatással lehetett mind a társadalomra, mind a gazdaságra (azon belül pl. a turizmusra) (Illés, 2007). A pálinka esetében a gyümölcs fontosságán túlmenően a helyi jelleg kap nagy hangsúlyt; tájjellegü termékről van szó, amely kultúránk fontos részét képezi a pálinkánál is éppúgy, mint a zöldségek, gyümölcsök területén (Gál, 2008).

2010-ben az elöállitási jogosultság tekintetében további engedményt tettek a jövedéki szabályozásban. Ezzel teret engedtek a maximum 100 liter ürtartalmú fözőüst magánbirtokban tartásának. A 2003. évi CXXVII. törvény értelmében: „Magánfözésben a párlatnak a magánfözö lakóhelyén vagy gyümölcsöse helyén használható, legfeljebb 100 liter ürtartalmú, párlat-elöállítás céljára kialakított desztillálóberendezésen a magánföző által végzett előállitása évente legfeljebb 2 hektoliter tiszta szesz mennyiségig engedélyezett" (hatályos 2010.09.27-töl).

Ezzel egyidejüleg módosultak az elöállításra került jövedéki termékek (pálinka) után fizetendő adójogszabályok. Az adóalapja minden esetben az elóállításra került és számba vehető 100 térfogat százalékos tartalommal hektoliterben meghatározott $20 \mathrm{C}$-on mért etil-alkohol mennyiség, illetve magánfözés esetén a vámhatósághoz bejelentett alapanyag mennyisége. Szeszfőzdében bérfőzés, valamint magánfözés keretében elöállított párlat után adóévenként legfeljebb 501 (gyümölcsszesz liter) mennyiségig 0 forint, az 501 meghaladó mennyiség után 333385 forint/100 hlf megfizetésére kötelezett.

Amennyiben a magánföző, a magánfözés keretében meghaladja az elöállított 50 liter mennyiséget, az adott adóévben adóbevallási és adófizetési kötelezettség terheli. Fel kell hívni a figyelmet arra is, hogy a pálinkafözés során, a gyümölcs feldolgozása folyamatában, több fázisban hulladék keletkezik, amely - adott esetben - veszélyes hulladéknak minősül. Az előpárlat és az utópárlat toxikus vegyületeket tartalmaz, illetve fémes mellékíze miatt nem használható, továbbá a cefre maradványa is hulladék. Ezeket az anyagokat a környezeti piacon, a jogszabályoknak és a társadalmi normáknak megfelelö módon kezelni kell, elhelyezni szükséges (Gál, 2003). Aggodalomra adhat okot, hogy az otthoni fözésnél ezen anyagoknak mi lesz a sorsa? 


\section{Anyag és módszer}

\subsection{Szekunder kutatás}

A szekunder adatok, már létező, azaz már valamilyen célból összegyüjtött adatok. A másodlagos forrásaink a témával kapcsolatos szakirodalmi munkák és az interneten található információk. Az irodalmi áttekintésben leirtuk a pálinka fogalmát, összefoglaltuk a pálinka adózásának történetét.

\subsection{Primer kutatás}

A primer adatok megszerzésének két módszere van, a kvalitativ (minőségi) és a kvantitatív (mennyiségi). Ez a két eljárás nem helyettesíti, hanem kiegészíti egymást. A minöségi eljárás strukturáltan feltáró kutatási módszer, amely kis mintán alapul, és a probléma természetének megértéséhez járul hozzá (pl.: interjúkészítés). A mennyiségi eljárásnak célja a hipotézisek alátámasztására olyan adatok keresése, ami statisztikailag értékelhetök, számszerüsíthetők (pl.: kérdőívkészítés). A megfigyelés, a kísérlet, a megkérdezés az elsödleges adatgyüjtés fö módszerei. A kutatásunk során a megkérdezéses adatgyüjtésen belül, a kérdőiv és az interjú eljárásmódját választottuk (Horváth, 2004).

\subsubsection{Kérdöiv}

A kérdőivet a békés megyei bérfözetökkel töltettuik ki 2014 szeptemberében, annak érdekében, hogy megtudjuk, mi a személyes véleményük a változtatásokról és a kapott válaszokból következtetéseket vonjunk le. A kapcsolatot személyesen vettük fel velük a bérszeszfőzdékben. A kérdőívet pár sor bemutatkozással kezdtük, valamint ismertettük a kutatásunk célját. Biztosítottuk a válaszadókat az anonimitásról. Összesen 16 kérdésböl állt a kérdőív, a kitöltők száma 141 fổ volt, a kiértékelhető kérdöívek száma $141 \mathrm{db}$.

A leggyakoribb kérdéstípusok, amiket alkalmaztunk nyitott és zárt kérdések (Horváth, 2004):

- Nyitott kérdésekre a válaszadó saját szavaival válaszol.

- Zárt kérdések azok, amelyekre elöre megadott választ adunk, és a válaszadónak választania kell közülük. Ezen belül lehetnek alternatív (eldöntendő), szelektiv (ebben az esetben elöre megadjuk a válaszlehetőségeket, de helyet biztositunk az önálló vélemény kifejtésére is), és skálarendszeres (amikor nem csak minösítünk, de a válasz intenzitását is megadjuk) típusúak (Horváth, 2004).

- Tényre vonatkozó kérdések (pl.: életkor, nem), sorba rendezési kérdés, valamint értékelő kérdés.

Figyeltünk arra, hogy kövessük a kẻrdöívkészités szabályait (Horváth, 2004):

- Egyszerü, érthetö, határozott, egyértelmü kérdéseket tegyünk fel.

- Nyelvezete érthető legyen. 
- Ne tegyünk fel túl sok kérdést.

- A kérdések változatosak legyenek.

- Ne használjunk befolyásoló vagy rávezethető kérdéseket.

A kérdések célszerü sorrendje (Horváth, 2004):

1.) Bevezető kérdések,

2.) Bemelegitő kérdések,

3.) Fö téma kérdései.

A bevezető kérdés feltevése azért lényeges, hogy kiszürjük azokat az embereket, akik nem jártasak a témában. A bemelegitő kérdések segítenek ráhangolódni a tárgyra, majd az utolsó részben rá lehet térni a kulcsfontosságú témákra.

A kérdöivezés hátránya, hogy a válaszadók nehezen elérhetök, és ha el is ériük öket, lehet passzivan állnak a kitöltéséhez. A kérdőiveket az SPSS program segítségével értékeltük ki.

\subsubsection{Interjui}

A témában jártas 5 fövel készíttettünk interjút szintén 2014 szeptemberében. Két kereskedelmi, és egy bérszeszfözde üzemeltetőjével beszélgettünk a 2010-ben bevezetett jogszabályokról, valamint két olyan személyt kérdeztünk meg a véleményéröl, tapasztalatairól, akik megpróbálkoztak a magánfözéssel.

\section{Vizsgálat és eredményeinek értékelése}

\subsection{Kérdöív kiértékelés}

A kérdőívet összesen 141 bérfözetővel töltettük ki. Összesen 15 kérdést kellett megválaszolniuk. Egyes kérdésnél indoklást is kértünk. A füzesgyarmati és a köröstarcsai szeszfözdében vettük fel velük a kapcsolatot, ezáltal - ha úgy engedte idejük - személyesen is el lehetett beszélgetni, ami során több dolgot lehetett megtudni a véleményükröl, nézetükröl.

A kérdőívben két kérdés a demográfiai adatokra kérdezett rá. A bérfözetők korcsoportjának és a nemek arányának megoszlásának vizsgálata volt a célunk.

A kitöltők közül 34 személy nö volt, 107 személy pedig férfi. A bérfőzetők nagy többsége, $76 \%$-a férfi.

Az egyik hipotézisünkben azt feltételeztük, hogy javarészt a 45 évnél idősebb személyek fözetnek bérfözés keretében. A felmérésböl kiderült, hogy a válaszadók többsége (73\%) a 45-55, 56-65 és a 65 év feletti korosztályba tartozik. Meglepöen tapasztaltuk, hogy a fözetök $21 \%$-a már betöltötte a 65 . életévét. Indoklásként azt a választ kaptuk, hogy ők inkább a szeszfơzdében előállított, tiszta pálinkát részesítik elönyben, ugyanis így pontosan tudják, mit isznak. A feltételezésünk, hogy a 45 évesnél idősebb korosztály fözet szívesebben pálinkát, bebizonyosodott (73\%). 
A kitöltők 76\%-a már 2010-et megelőzően is fözetett pálinkát. Természetesen pár személy megemlitette, hogy 2010 elött 1-2 évben volt, hogy nem fözettett, mivel nem volt elegendő mennyiségü gyümölcsük, de ez a tényező a kutatás szempontjából elhanyagolható, mivel a 2010-14-es időszakot vizsgáltuk. 18 válaszadó $1-3$ éve, 15 pedig pontosan 2010 óta állittat elö pálinkát.

A megkérdezettek $65 \%$-át nem befolyásolta a $0 \mathrm{Ft}$-os adótétel bevezetése. Indoklásuk egyöntetü volt, miszerint ha van megfelelö mennyiségü, cefrének alkalmas gyümölcsük, természetesen kifözetik. Bár anyagi szempontból jobban megéri, mégsem fözetnek ennek köszönhetően több mennyiséget, csak ami megterem nekik. 46 embertöl (33\%) azt a választ kaptuk, hogy befolyásolta őket.

Közülük többen emiatt kezdtek el fözetni. Mások a korábbi évekhez képest, nagyobb mennyiségü cefrét fözetnek ki, de nem érik el a 43 hlf mennyiséget. Pár ember pedig azzal indokolta, hogy a $0 \mathrm{Ft}$-os adófizetési kötelezettségnek hála, nem kell elgondolkodniuk azon, hogy kifözessék-e a megtermett gyümölcsüket, vagy sem. Az egyéb válaszlehetőséget az a 3 fö adta meg, akik nem saját maguk, hanem a párjuk, élettársuk döntött ebben a kérdésben.

Az SPSS program segítségével megvizsgáltuk a fözési gyakorlat kezdetét és a $0 \mathrm{Ft}$-os adótétel kapcsolatát. Akit befolyásolt a 0 forintos adókötelezettség, azok közül 30-an, már 2010 elött is fözettek. 10-en csak ennek hatására 2010-ben kezdtek el, 3 személy pedig csak 1-3 éve fözet. Akiket nem befolyásolt, azok legnagyobb része már 2010 elött is állíttatott elő pálinkát. 10 fö csupán 1-3 éve veszi igénybe a fözdék szolgáltatását, és öket sem befolyásolta a jövedéki termékre meghozott adózási kötelezettségek változása.

Az indoklások a következök voltak: Csak pár éve rendelkeznek gyümölcsössel, vagy nem régen költöztek a térségbe, és azelött nem foglalkoztak ilyesmivel. 5 olyan kérdőív kitöltő volt, akik pontosan 2010 óta fözetnek, viszont öket sem befolyásolta az adótétel. A vizsgálat során levonhatók a következtetések, miszerint a régebb óta főzető személyek álláspontja szerint, nem gyakorolt rájuk nagy hatást a 0 forintos adótétel. Ez a megállapitás nem azt jelenti, hogy figyelmen kívül hagyták, hanem, hogy az előző évekhez hasonló, és nem nagyobb mennyiségben fözetnek. A kérdőív kitöltése közben megejtett beszélgetés során, természetesen mindenki pozitívnak gondolja a meghozott rendeletet, mivel nem kell adót fizetniük 43 hlf-ig. Az egy liter 50 V/V pálinkára eső elöállítási költség lényegesen csökkent. Ennek következtében a 86 liter 50 fokos pálinka mértékéig az összes megtermett gyümölcsöt ily módon hasznosítják, nem hagyják kárba veszni.

A megkérdezettek közül $94 \%, 132$ fö nem kísérletezett az otthoni fözéssel 2010 óta. 6\%-a, tehát 9 személy fözött otthon az utóbbi 4 évben legálisan pálinkát. Meg kell említeni, hogy a meghozott Jövedéki Törvény $63 \S(7)$ bekezdése alapján, egy háztartáson belül vagy magánfözés, vagy bérfözetés keretében lehet pálinkát előállítani. A két tevékenységet egyszerre nem lehet végezni. 


\section{1. ábra: A megkérdezettek indokai, hogy miért nem próbálkoztak otthon} párlatot fözni $(\mathrm{n}=132)$

\section{Miért nem próbálkozott otthon fözni?}

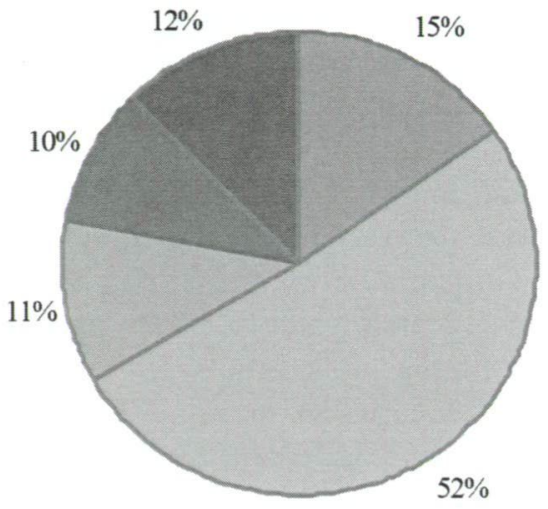

A magas előállítási költség miatt

Gyakorlati tapasztalat

hiánya miatt

Időhiány miatt

Kényelem miatt

Egyéb

Forrás: Saját gyüjtésű adatok, saját szerkesztés

Rákérdeztünk az elöbb említett 132 embernél, hogy miért nem próbált otthon pálinkát előállítani. A válaszadók 15\%-a a magas elöállítási költség miatt.

Véleményük szerint olcsóbb megoldás, ha a bérszeszfőzdébe viszik cefréjüket, valamint a berendezés ára, csak hosszú távon térülne meg. A legtöbben $(52 \%)$ a gyakorlati tapasztalat hiánya miatt nem fogott bele a magánfözésbe, azt állítják, hogy a pálinkafózés egy szakma, amit az embernek ki kell tanulnia. 11\%-ának nem lenne ideje rá. 15 embernek pedig kényelmesebb kivinni az alapanyagot a fözdébe, és minden aggodalom nélkül kimenni a már kifözött jó minőségű pálinkáért. $15 \%$-a az egyéb válaszlehetőséget adta meg. Sokan a koruk miatt nem kezdtek bele, voltak, akik féltek, mert veszélyesnek tartották. Emellett volt olyan, aki az összes válaszlehetőséget lényegesnek tartotta.

Megállapítható, hogy az emberek nagy részének véleménye szerint, a magánfözés esetében nélkülözhetetlen a szakértelem és tapasztalat. Ennek hiányában nem szivesen fognak bele.

A megkérdezettek közül, csupán 9 ember próbálkozott az otthoni fözéssel. 7-en közülük szabadidős tevékenységként kezdték el. Ebből 5 ember azért nem föz már otthon, mivel az elöállított pálinka mennyiségével és minőségével nem volt megelégedve, így visszatért a szeszfözdébe bérfőzetőként. A másik két válaszadó pedig időhiány miatt adta fel. Egy ember, anyagi okok miatt fogott bele, ugyanis úgy gondolta, hogy az otthoni berendezésen olcsóbban tudja előállítani a pálinkát.

Végül a magas költségek miatt abbahagyta ezt a tevékenységet. Ugyancsak emiatt fejezte be az otthoni fözést, azaz illető, aki azért vágott bele, hogy szakmailag képezze magát. A kevés adat tekintetében, nem vonhatunk le konklúziót. 
További kérdésünk volt, hogy a kitöltők szándékoznak-e a jövöben fözőkészüléket venni? $100 \%$, tehát 141 személy egyértelmüen nem kíván ilyen berendezést vásárolni. $\mathrm{Az}$ indokolás majdnem minden esetben a 1 . ábrán feltüntetett tényezök voltak. Pár személy viszont azt válaszolta, hogy azért nem fog ilyenre pénzt kiadni, mert véleményük szerint ezt a törvényt el fogják törölni.

A továbbiakban arra kerestük a választ, hogy a megkérdezettek hány százaléka gondolja pozitivnak vagy negatínnak azt, hogy megengedték a legfeljebb 100 liter űrtartalmú párlat-elöállítás céljára kialakított desztillálóberendezés magánbirtokban tartását. A megkérdezettek $65 \%$-a negatívnak gondolja. Saját véleményük szerint ez a tevékenység veszélyes. Egyrészt azért, mert hallották a médiában, hogy volt, akinek a berendezése felrobbant. Másrészt azért, mert nem megfelelö minőségü pálinkát állítanak elö rajta, nem tudják beállítani a helyes szeszfokot, így magasabb lehet benne az etil-alkohol arány, ami káros hatással van az emberi szervezetre.

Sokan azt az indokot irták, hogy az illetök, akik otthon föznek, biztos nem tartják be a 43 hlf-os korlátot, tehát ezen felül föznek, és mivel nincs bejelentési kötelezettségük, igy nem fizetik ki az utána eső adót, ami lényegében az állami bevétel számára kiesést jelent. Ezen kívül meggyőződésük van arról, hogy nem csak a saját, hanem a szomszéd, ismerős cefréjét is kifözik a desztillálóberendezésen. $35 \%, 49$ fő meglátása szerint pozitiv. Ök azzal indokolták válaszukat, miszerint ezzel a törvénnyel nagyobb szabadságot adnak az embereknek, valamint egyetértenek azzal a ténnyel, hogy aki tudja, az csinálja. Pár ember azzal érvelt, hogy akinek kevesebb mennyiségü cefréje van, annak jobban megéri a házi pálinkafőző berendezést alkalmaznia, így biztosan a saját alapanyagból készült pálinkáját ihatja. Levonható az a következtetés, miképpen az emberek nagy része a magánfözést nem preferálja a fent megemlitett tények miatt.

Vajon azok az a megkérdezettek, akik már próbálkoztak az otthoni fözéssel, negatív, vagy pozitív választ adtak az elöző kérdésre? A keresett adatokat az 1 . táblázat mutatja.

\section{1. táblázat: Az otthonfözés és ennek pozitív/negatív megítélése közötti} összefüggések $(n=141)$

\begin{tabular}{|c|c|c|c|c|}
\hline & \multicolumn{2}{|c|}{$\begin{array}{c}\text { Véleménye szerint, az a lehetōség, } \\
\text { hogy engedélyezték a } \\
\text { magánszemélyeknek az otthoni } \\
\text { pálinkafôzést pozitív, vagy negativ? }\end{array}$} & \multirow[t]{2}{*}{ Total } \\
\hline & & Negativ & Pozitiv & \\
\hline \multirow{2}{*}{$\begin{array}{l}\text { Amióta engedélyezve van, } \\
\text { hogy magánszemély otthon is } \\
\text { állíthat elö pálinkát, azóta } \\
\text { kisérletezett-e ezzel a } \\
\text { tevékenységgel? }\end{array}$} & Igen & 2 & 7 & 9 \\
\hline & Nem & 90 & 42 & 132 \\
\hline Total & & 92 & 49 & 141 \\
\hline
\end{tabular}

Forrás: Saját gyưjtésũ adatok, SPSS program által összeállitott táblázat

Azok közül, akik az utóbbi 4 évben föztek otthon párlatot, 7 ember vélekedik pozitivan a meghozott törvényről. 2 ember, bár élt a törvény adta lehetöséggel, 
mégis negativ véleményt alkotott az otthoni fözésröl. Tapasztalataik alapján nem lehet ekkora fözőkészüléken minőségi terméket elöállítani. Az általuk fözött pálinka, ihatatlan volt, és magas etil-alkoholt tartalmazott. Úgy gondolják, hogy egyéb kitételeket is meg kellene hozni a rendeletben - pl.: szakmai hozzáértést -, vagy növelni a megengedett ürtartalom mennyiséget, és a bejelentési kötelezettséget bevezetni. A pozitívan vélekedő személyek, akik felhagytak a tevékenységgel, azzal indokolták, holott ök nem tudták megfelelöen, reális költségen belül előállítani az általuk kivánt terméket, mégis aki ért hozzá, annak legyen törvényes módja tovább folytatni a tevékenységet.

Vizsgálat továbbá kiterjedt arra a kérdésre, miszerint a (45 évnél) fiatalabb, vagy a (45 évnél) idősebb korosztály ért egyet a jogaszály változások liberalizálásával. Az adatokat a 2. táblázatban foglaltuk össze.

2. táblázat: A megkérdezettek életkorának, és a magánfözésról való véleményüknek a vizsgálata $(n=141)$

\begin{tabular}{|c|c|c|c|c|}
\hline & \multicolumn{2}{|c|}{$\begin{array}{l}\text { Véleménye szerint, az a lehetôség, hogy } \\
\text { engedélyezték a magánszemélyeknek az } \\
\text { otthoni pálinkafózést pozitiv, vagy } \\
\text { negatív? }\end{array}$} & \multirow[t]{2}{*}{ Total } \\
\hline & & Negatív & Pozitiv & \\
\hline \multirow{4}{*}{ Életkor } & $18-45$ & 24 & 14 & 38 \\
\hline & 46-55 & 18 & 13 & 31 \\
\hline & 56-65 & 33 & 9 & 42 \\
\hline & 65 év felett & 17 & 13 & 30 \\
\hline \multicolumn{2}{|l|}{ Total } & 92 & 49 & 141 \\
\hline
\end{tabular}

Forrás: Forrás: Saját gyújitésủ adatok, SPSS program által összeállitott táblázat

A 18 és 45 év közötti 38 fö válaszadó közül 24 személy negatívnak, 14 személy pozitívnak gondolja. A 46-55 közötti korcsoportból 18 -an nem értenek egyet a magánfözéssel, 13-an pedig igen. Az 56-65 év közöttiek esetében a 42 személyböl 33 vélekedik negativan erről. A 65 év felettiek esetében a 30 megkérdezettböl 17-en ellene, 13-an mellette vannak a meghozott törvénynek.

Látható, hogy a 45 év alattiak jóval kevesebben vannak, mint az idősebbek, igy a tisztán látás érdekében, nézzük százalékos formában a kapott eredményeket! A 45 évnél fiatalabbak 37\%-ának pozitiv, $63 \%$-ának negativ a meglátása az otthoni fözésröl. Az idősebb korosztály esetében hasonló eredményeket kaptunk. 34\%-a egyetért, hogy behozták ezt a törvényt, $66 \%$-a pedig ellenkezőleg vélekedik a dologról. Levonható az a következtetés, hogy a szeszfözökészülékek magánbirtokban tartásáról az idősebbek és a fiatalabbak is hasonlóan gondolkodnak. Egyik csoport sem preferálja jobban, mint a másik, természetesen a megkérdezettek körében.

Feltettük azt a kérdést a bérfözetöknek, hogy van-e olyan ismerősük, akik otthon, saját berendezésen fözik ki a cefréjüket. $59 \%$ azt mondta, nem ismer ilyen személyt. $36 \%$ azaz 51 fözető 1-2 illetőről tudja, hogy magánföző berendezéssel rendelkezik. 6\% 3-5 ilyen tevékenységet végző föt ismer. Egy ember pedig több mint 5 olyan ismerőssel rendelkezik, aki otthon föz pálinkát. Meg kell említenünk - 
mivel a megkérdezettek nagy része egy településen él - hogy átfedések is lehetnek. Tehát több válaszadó gondolhatott ugyanarra a személyre. Mivel a kitöltés anonim módon történt, igy nem kérhettük meg őket a személyek megjelölésére. Ennek következtében nem tudunk pontos számot adni arról, hányan rendelkeznek otthoni fözőkészülékkel a bérfözetök ismerösei között.

A továbbiakban megkérdeztük, hogy hány bérfớzetőnek van tudomása olyan személyről, aki bár megpróbálkozott az utóbbi 4 évben az otthonfözéssel, mégis felhagyott vele. $84 \%$-ának az ismeretségi körében nincs ilyen személy. 22 ember pedig 1-2 föröl tud, aki befejezte a legális otthoni párlat elöállítást. Tölük arra is választ kaptunk, miért hagytak fel ezzel a tevékenységgel. A lehetöségek közül legtöbben (8-an) a gyakorlati tapasztalat hiányát jelölték meg, 6 ember tudomása szerint az, akit ismernek nem volt megelégedve az általa elöállított pálinka mennyiségével és minőségével. Öt személy úgy hallotta, hogy aki leállt a fözéssel a magas előállitási költség miatt tette. Három fö úgy értesült, miszerint ismerőse idő hiảnyában nem folytatta a magánfözést.

Kérdéseink kiterjedek arra, hogy vajon a bérfözetők közül, hány személy fözetné ki cefréjét, ha az elóállított termék mennyisége túllépi a 86 litert - a $0 \mathrm{Ft}$ adófizetési kötelezettség keretét - és a felette keletkezö tétel után meg kellene fizetnie az adót. A válaszadók 49\%-a kifözetné. Válaszukat azzal indokolták, hogy már 2010 elött is kifizették az adót, az elöállitott pálinka után, igy természetesen, ha megteremne nekik az a gyümölcsmennyiség, amit pálinkafözés céljára használnának fel, gondolkodás nélkül vállalnák a rájuk kiszabott adó megfizetését. $51 \%$, tehát 72 fö a nem válasz mellett döntött. Ök azért nem fözetnék ki, mert nincs szükségük akkora mennyiségre, és nem is tudnának vele mit kezdeni. Ezen kivül drágának vélik az adó mértékét, így inkább lemondanának arról a mennyiségről.

Azon személyek közül, akiket befolyásolt a 0 forintos adótétel, 13-an mégis kifözetnék cefréjüket. Ök azért fizetnék ki utána az adót, mert ha már megtermett a gyümölcs nem akarják, hogy kárba vesszen, illetve szerintük, még így is megéri, mert 86 literig nem kell kifizetni. 33 bérfözető a nemmel válaszol. Egy részük a 0 forintos adófizetési kötelezettség miatt kezdett bele a bérfözetésbe, mások a 86 litert elegendỏ mennyiségnek tarțák. Harmadrészt olyan választ is kaptunk, hogy azért nem fözetik ki, mert nem szeretnek adót fizetni. 92 személyt nem befolyásolt az adóváltozás. 55-en közülük elöállíttatná a 86 liter feletti pálinka mennyiséget. 2010 elött is kifizették, és ha lenne ekkora mennyiségük, ezután is kifizetnék. 37-en viszont nem. A kapott válaszok szerint, nekik is elegendő ez a mennyiség, illetve, ha már 43 hlf-ig nem kell fizetni adót, akkor ök ennyi mennyiségig fözetnének.

Az előzőekböl levonhatók a következtetések, miszerint a bérfözetők fele, ha lenne rá lehetősége, kifözetné az adóköteles tételt is. A másik fele, ellenben nem, mivel elég neki az alatta lévő mennyiség, és nem szívesen fizetne adót.

Mi a legfontosabb szempont a bérfözetők számára a pálinka kifözésénél? Megkértük a kitöltőket, rangsorolják 1-től 4-es skálán az alábbi szempontokat: a pálinka minősége, a pálinka mennyisége, a pálinka előállitási idejének rövidsége, és a 0 forintos adótétel (3. táblázat). 
3. táblázat: A legfontosabb szempont a bérfözetők számára a pálinka kifőzésénél?

\begin{tabular}{|c|c|c|c|}
\hline & \multicolumn{2}{|c|}{ Az 1. helyre sorolt } \\
\hline & & fo & $\%$ \\
\hline \multirow{4}{*}{ Szempontok } & A pálinka minösége & 136 & 96,5 \\
\hline & $\begin{array}{ll}\text { A } & \text { pálinka } \\
\text { mennyisége }\end{array}$ & 1 & 0,7 \\
\hline & $\begin{array}{l}\text { Az elóállítási } \\
\text { idejének rövidsége }\end{array}$ & 1 & 0,7 \\
\hline & A 0 Ft-os adótétel & 3 & 2,1 \\
\hline \multicolumn{2}{|l|}{ Total } & 141 & 100,0 \\
\hline
\end{tabular}

Forrás: saját gyüjtésū adatok

A válaszadók $96,5 \%$-a tehát 136 ember számára a pálinka minösége a legfontosabb. Egy személynek a mennyiség a leglényegesebb. Egy bérfözetőnek, azaz elsö, hogy időben kifójön pálinkája. Három fö pedig a 0 forintos adótételt helyezte az első helyre. Kérdés nélkül a megállapitás, az hogy a minőséget preferálják elsősorban az emberek.

\section{4. táblázat: A második legfontosabb szempont a bérfözetők számára a pálinka} kifözésénél?

\begin{tabular}{|c|c|c|c|}
\hline & \multicolumn{2}{|c|}{ A 2. helyre sorolt } \\
\hline & & fó & $\%$ \\
\hline \multirow{4}{*}{ Szempontok } & A pálinka minôsége & 4 & 2,8 \\
\hline & $\begin{array}{l}\text { A pálinka } \\
\text { mennyisége }\end{array}$ & 49 & 34,8 \\
\hline & $\begin{array}{l}\text { Az elõállítási } \\
\text { idejének rövidsége }\end{array}$ & 16 & 11,3 \\
\hline & A 0 Ft-os adótétel & 72 & 51,1 \\
\hline \multicolumn{2}{|l|}{ Total } & 141 & 100,0 \\
\hline
\end{tabular}

Forrás: Saját gyüjtésü adatok, SPSS program által összeállított táblázat

A 4. táblázatban látható, melyik szempontot helyezték a 2 . helyre. A megkérdezettek fele a nulla forintos adókötelezettséget tette a fontossági sorrend 2 . helyére. 49 bérfözető a második helyre a mennyiséget helyezte. 16 embernek a minöség után az előállitási idő rövidsége a legszámottevőbb.

$\mathrm{Az}$ eredmények arra enged következtetni, hogy a bérfözetök elsősorban a minőséget részesítik elönyben, majd másodlagosan a nulla forintos adótételt. Véleményük alapján a mennyiség és az elöállítási idö rövidsége e tényezök mellett elhanyagolható. Pár személy megemlítette, hogy számára fontos még a fözde tisztasága, ugyanis jártak olyan helyen, ahol rossz tapasztalatokat szereztek e tekintetben.

Továbbá vizsgáltuk azt az összefüggést is, miszerint akik nem fözetnék ki 43 hlf felett a cefréjüket, hányadik helyre sorolták a $0 \mathrm{Ft}$-os adótételt. Összesen 72 személy nem fözetné ki a pálinkáját 43 hlf felett. Több mint a fele, 45 bérfözető az adótételt a második helyre sorolta, ebböl levonható a következtetés, hogy számukra kulcsfontosságú szerepe van a fözetésnél a 0 forintos adókötelezettségnek. (A 3. 
táblázatra hivatkozva, egyértelmü hogy a kitöltők számára a pálinka minősége a legmeghatározóbb.) Két válaszadó számára, ez a tényező a legfontosabb. A maradék 25 személy a 3 . illetve a 4 . helyre sorolta. Indoklásuk az volt, hogy bár lényeges számukra a nulla forintos adótétel - mert nem kívánnak adót fizetni a pálinka után, valamint nem is fözetnék ki az adóköteles mennyiséget - mégis úgy vélik, hogy a többi három válaszlehetőség - a pálinka minősége, mennyisége, és elöállítási idejének rövidsége - jelentősebb számukra.

\subsection{Interjủ egy bérszeszfözde üzemeltetöjével}

Interjút készitettünk a köröstarcsai és füzesgyarmati bérszeszfözde üzemeltetöjével. A véleményét kérdeztük a 2010-ben bevezetett jogszabályváltozásokról, ezen belül az adózási kötelezettségek változásáról, valamint az elöállítási jogosultság területén tett engedményröl. Ezen kívül rákérdeztem, milyen hatással voltak az említett módosítások a bérszeszfözdékre. Az interjú során 15 kérdést tettem fel, melyre készségesen válaszolt.

Molnár Sándor a köröstarcsai bérszeszfözdét 2008 óta, még a füzesgyarmati fözdét 2009 óta üzemelteti. A tulajdonossal bérleti szerződéses viszonyban vannak.

Már ezeket az éveket megelözően, több mint 20 éve fözet pálinkát Köröstarcsán, igy ismerte a tulajdonost, valamint a rendszert, de emellett több tényező is befolyásolta, hogy belefogjon ebbe a tevékenységbe. Egyrészt a korábbi munkahelyén az egyik szakfeladata volt a bér- és kereskedelmi szeszfözdék ellenörzése és elszámoltatása. Nyugodtan kijelentette, hogy a müködésükkel kapcsolatban teljes rálátással rendelkezett már a korábbi években is. Másrészt az általa üzemeltett szeszfözdék tulajdonosai más területen kezdtek el dolgozni, és a korábbi ismertség révén felajánlották az üzemeltetési lehetőséget számára. Nem utolsósorban az időszakos munkára tekintettel, családjának bevételi forrást jelent.

A kérdőíves vizsgálat során, sok személy úgy vélekedett a pálinkafözésröl, mint egy szakmáról. Az interjú során, rákérdeztünk, hogy az alany is így vélekedike. Ő a Vám- és Pénzügyőrségen eltöltött több mint 23 év alatt a szükséges elméleti és gyakorlati tudást megszerezte, emellett a felelős szeszfözde vezetöi tanfolyamot elvégezte, ami nélkül, nem lehet bérszeszfözdét üzemeltetni. Véleménye szerint ugyancsak fontos elsajátítani a megfelelő szaktudást a pálinkafőzés és az azt megelöző tevékenységek területén (cefrekészités), annak érdekében, hogy reális költségek mellett, minőségi terméket állítson elő az ember. Érdeklődtünk az iránt, mi a véleménye, hogy 2010-ben teret engedtek a maximum 100 liter ürtartalmú fözöüst magánbirtokban tartásáról. A törvény meghozatalával egyetért, mert biztosítja a demokráciában, a szabad lehetőséget bárki számára. Ennek ellenére a törvény végrehajtásával kapcsolatos rendeletet, jelenlegi állapotában nem tudja elfogadni, mert nincs bejelentési kötelezettségük a magánfözőknek (2014 szeptember), a berendezések nincsenek nyilvántartva, így az azokon előállított mennyiség ellenőrzése elmarad. Továbbá kíváncsiak voltunk, mit gondol, mi lehetett az indoka a törvény megalkotásának. Saját véleménye szerint, egyik indok lehet az EU-ba való belépés. Az Unióhoz való csatlakozást követően a magyar jogszabályokat kötelesek kompatibilissé tenni az EU-s tagállamok jogszabályaival. 
Tudomása szerint más tagállamokban a nemzeti italnak tekintendő termékeket - példaként emlitette Írországot, ahol a whisky-t, Németországot, ahol a sört engedélyezik otthon elöállítani. Viszont ezekben az országokban a magánfözőket ellenörzés alá vonják, tehát bejelentési kötelezettségük van.

Bár a szakmai tapasztalata meg van hozzá, az interjúalany nem próbálkozott az otthoni fözéssel. Véleménye szerint kis mennyiségben, minőségi pálinkát nem lehet ekkora fözőkészüléken előállítani, valamint a készülék használata a nyert párlat tekintetében nagyon költséges. Jobban megéri számára, ha a szeszfözdében fözeti ki a kivánt cefrét, és ez által aromásabb, ízletesebb pálinkát kap. Az interjú alany 2 föt ismer, aki 2010 óta, mai napig legálisan föz otthon pálinkát. A kapott visszajelzések szerint, ezeknek az embereknek meg van hozzá a kellő szakmai érzéke, és jó minőségü párlatot állítanak elő. Ugyancsak 2 személyt ismer, akik bár megpróbálkoztak az otthoni magánfözéssel, de a magas előállitási költség és az alacsonyabb minőségü produktum miatt felhagytak ezzel a tevékenységgel, és inkább a bérszeszfözdék szolgáltatásait vették újra igénybe. Sok embertöl hallotta, hogy vannak, akik a szakmai tudás hiányában hagynak fel a fözéssel, ezen kivül több helyen már balesetet is okozott a tapasztalat hiảnya.

A magánfözésen túl elbeszélgettünk a 2010-ben bevezetett adózási jogszabályról. A 43 hlf-ig megállapitott $0 \mathrm{Ft}$ adófizetési kötelezettséget elfogadja, és pozitívnak tartja. Ezen lehetöséget kihasználva több személy juthat, olcsóbb elállítási költség mellett kiváló minőségü termékhez. Az utóbbi éveket nézve, a bérszeszfözdékben megjelent az a réteg, akik csak a $0 \mathrm{Ft}$-os adótétel megfizetése mellett tudja maga számára elöállítatni a családi szükségletet. Megemelkedett a bérfözetők száma, és megjelent egy olyan igényes fiatal réteg is, aki a gyümölcsböl saját maga részére pálinkát állíttat elő. Korábbi tapasztalata alapján, elmondta, hogy 15-20 évvel ezelőtt a pálinkafözést túlnyomórészt bérfözés keretében csak az idős korosztály müvelte.

Már hetek, hónapok óta foglalkozik a média azzal a kérdéssel, hogy az EU 2011-ben kötelezettségszegési eljárást inditott Magyarország ellen a bevezetett törvény miatt (2014 szeptember). Molnár Sándor véleménye szerint magát a törvényt meg kell tartani, ezáltal a legmagasabb jogi szinten biztosítani kell a lehetőséget, hogy bárki otthon állíthasson elő pálinkát. A törvényhez tartozó végrehajtási rendeletet viszont módosítani kell, az elöállítási jogosultsággal kapcsolatban bejelentési, nyilvántartási, ellenőrzési és elszámoltatási kötelezettséget kell elöírni, magát a készüléket hivatalos zár alatt kell tartani, ezáltal a visszaéléseket el lehet kerülni.

\subsection{Interjú, a kereskedelmi szeszfö̈zde üzemeltetóivel}

Kutatásunk során szükségszerünek gondoltuk a témában kellö szakmai tudással és jártassággal rendelkező, nagyüzemben termelő személyek megkérdezését a bevezetett jogszabályokról és azok hatásairól. Egy kereskedelmi fözde üzemeltetőjével, és egy kereskedelmi fözde jövedéki ügyintézöjével vettük fel a kapcsolatot, akik megosztották velünk ismereteiket, tapasztalataikat, véleményüket. 
$\mathrm{Az}$ egyik interjú alanyunk Tóth János volt a sarkadi Éden-tó szeszfözde üzemeltetője. A másik megkérdezett, Kindli Péter a Pálinkaszolgáltató Kft. jövedéki ügyintézöje volt. Nézőpontjuk hasonló volt, ezért a terjedelmi korátokra hivatkozva jelen tanulmányban csak a Tóth Jánossal folytatott beszélgetés eredményeit közöljük. 17 kérdést állítottunk össze, amelyekre figyelmesen válaszolt. Már 26 éve foglalkozik bérfözéssel, ennél fogva meg van a kellő tapasztalata, szaktudása a témával kapcsolatban. A kereskedelmi fözést 5 éve üzi.

Azért választotta ezt a szakmát, mert családalapitás folytán szeszfözde közelébe került, ezáltal megtetszett számára a munka sokszínüsége, változatossága.

A szakmai tudás érdekében elvégezte a felelős szeszfözde vezetői tanfolyamot, valamint pálinka bírálói tréningekre is járt. Részt vett üzemlátogatásokon, szakmai rendezvényeken, konferenciákon. A bér- és kereskedelmi szeszfözdében kizárólag hagyományos kisüsti lepárlóberendezést alkalmaz, ugyanis ezt a készüléket preferálja. A beszélgetés során, rákérdeztünk milyen jogszabályváltozások hátráltatták, vagy juttatták előnyhöz a kereskedelmi főzés területén. Egyrészt folyamatosan megnehezíti az üzemeltetést, a jövedéki biztosíték magas összege, a szüntelenül emelkedő jövedéki adó, az ügyintéző, könyvvizsgáló költsége, mindemellett a számítógépes adatszolgáltatás és a nyilvántartások bonyolultsága.

Megemlítette, hogy hátrányosan érintette a házi pálinkafőzés engedélyezése. Miután megengedték a maximum $1 \mathrm{db} 100$ liter ürtartalmú fözőüst magánbirtokban tartását, valamivel visszaesett a kereskedelemi forgalmú pálinkák értékesített mennyisége, de ezt számszaki adatokkal nem tudta alátámasztani. A bérszeszfózde szempontjából előnyhöz juttatta a 43 hlf-ig bevezetett 0 forint adófizetési kötelezettség, mivel ennek hatására jelentősen megnövekedett a bérfözetők száma az utóbbi 4 évben, viszont ez a jogszabály ugyancsak negatívan érintette a kereskedelmi fózés esetén. Érdeklődtünk az iránt, hogy véleménye szerint, mi indokolta a jövedéki termékekre vonatkozó adójogszabályok változását. Mivel a magánfözésben meghatározott mennyiségig adómentessé tették a pálinka fözését, így teljesen korrektnek látja, hogy a bérszeszfözésre is kiterjesztették. Szóvá tette, hogy a magánfözés különösebben nem zavarja, meglátása szerint a régióban nagymértékben nem érezhető a bérfözés területén. Ismerösei között van olyan, aki mai napig legálisan föz otthon pálinkát, viszont jó pár személyről tud, akik az időhiány, a hatalmas energia befektetés, a kétes minőség, és a hozzáértés hiánya miatt felhagyott ezzel a tevékenységgel. Meglátása szerint, pozitívumnak minösül a magánfözés, a kisebb cefremennyiség szeparált lefözhetősége miatt, ennek ellenére negativan vélekedik a bejelentési kötelezettség hiányáról, ugyanis meggyőződése van arról, hogy illegális bérfözö tevékenységet folytatnak. Azzal, hogy engedélyezték az otthonfözést, ellenőrizhetetlenné vált az előállitott mennyiség, így az esetlegesen megmaradt, fenntartott jövedéki adó beszedhetetlenné vált. Az interjúalany elmondta, hogy megfelelő szakértelemmel és technológiai rendszeren, minden további nélkül elő lehet állítani jó minőségü pálinkát. Tóth János elve szerint, a pálinkafözés nemhogy egy szakma, egy életforma is. 


\subsection{Magánfözökkel készittett interjú}

Kutatásunk kiterjedt azon személyekre, akik éltek azzal a lehetőséggel, hogy otthon fözzenek pálinkát. Személyes megkeresés után ketten vállalták, hogy válaszolnak kérdéseinkre, de azon feltétel mellett, hogy nem közölhetjük nevüket a tanulmányban, így az anonimitást biztosítottuk számukra. Már a magánfözéssel felhagyott személlyel, valamint egy mai napig otthon fözövel beszélgettünk a 2010-ben bevezetett jogszabályváltozásokról és az általuk szerzett tapasztalatokról.

\subsubsection{A magánfözéssel már felhagyott illetö válaszai}

$\mathrm{Az}$ interjú során, szintén 17 kérdést tettünk fel a volt magánfőzőnek. Még 2010 előtt, néhány évben, amikor a termés engedte, kivitte cefréjét a bérszeszfözdébe.

Fiatalabb korában nem foglalkozott ilyesmivel, csak 40 éves kora után kezdett érdeklödni a pálinkafözés iránt. Ebben az évben nem fözette ki cefréjét, mert kis mennyiség jött össze, valamint állagát tekintve, meglehetösen „leveses” volt. Azért döntött 2010-ben úgy, hogy megpróbálkozik az otthoni párlat elöállítással, mert érzett annyi tehetséget magában, hogy elkészitsen egy otthoni lepárlókészüléket, és azon keresztül pálinkát állitson elö. A berendezést saját maga állitotta össze, amelynek minden része réz alapanyagú. Két rézüst van összefordítva, az egyik 50 literes, a másik 30 liter ürtartalmú. Keverőtárcsa nélküli, emiatt csak levet tudott lefözni. Mivel saját, otthoni készítésü géppel kivánta előállítani a párlatot, jogkövetö emberként, kötelességének érezte bejelenteni készülékét a Nemzeti Adóés Vámhivatalhoz. A kérvényben lerajzolta a berendezés minden részét, müszaki rajzot, képet készitett róla, valamint részletesen leírta, milyen alapanyagokat használt fel hozzá. A kérelem benyújtása után, megkapta az engedélyt a NAV-tól, hogy otthon fözhessen. Érdeklödtünk aziránt, hogy elvégzett-e valamilyen iskolát, vagy tanfolyamot a témával kapcsolatban. Az interjúalany nem vett részt semmilyen képzésen, az elméleti tudást, és a gyakorlati tapasztalatot könyvböl, internetről közeli, távoli ismerösöktől tanulta el. A könyv, valamint az internetes oldalak címére már nem emlékezett, a személyes forrásainak nevét pedig nem kívánta közölni. Rákérdeztünk, milyen alapanyagból fözött általában otthon pálinkát. Többnyire különféle gyümölccsel próbálkozott, mivel azzal kísérletezett, melyikböl lenne a legjobb párlat, valamint annak is a függvénye volt, hogy éppen mikor, és mi termett meg a kertjében. Az egyik nyáron eperböl és cseresznyéből is igyekezett színvonalas párlatot készíteni, ősszel, szilvával és körtével is megpróbálkozott. A minőséget helyezte elötérbe, nem pedig a mennyiséget.

Meggyőződése arról, hogy jó pálinkát, csak jó cefréből lehet előállítani, így nagy figyelmet fordított a cefrézés lezajlására. Említettük neki, hogy a kérdöiv kitöltők véleménye szerint, a magánföző berendezések robbanásveszélyesek. Az érintett elmondta, miszerint az ő berendezése közvetlen tüzelésü, így ebben az esetben nem áll fenn a robbanás esélye. A duplafalú, gőzzel melegített üstöknél történhet ilyen eset, mivel azok nyomás alatt vannak. Tehát, ha a magánfözỏ a biztonságosabb, közvetlen tüzelésủ lepárló berendezést alkalmazza, nem kell tartania a robbanástól. Az interjúztatás során eljutottunk ahhoz a kérdéshez, hogy 
miért hagyott fel az otthoni fözéssel. Egyrészt saját tapasztalata alapján, egyértelmüen kijelentette, hogy nem tudta azt a minöséget produkálni, amit nagy tételben a bérszeszfözdében elöállítanak. Másrészt a költségek magasak voltak az elöállított termék mennyiségéhez képest, ezen kívül tetemes időt fordított rá, hogy az elvárt színvonalat megüsse. Ezen tényezök figyelembe vételével, úgy döntött, inkább felhagy ezzel a tevékenységgel. Meglátása szerint a törvény meghozatala pozitív, ugyanis akinek van ideje, szakmai tapasztalata, gyakorlata, megfelelő berendezése, az nyugodtan csinálja. Jó pár embert ismer, akik otthon föznek, de meglátása és tájékozottsága szerint, az ismerős magánfözők gyári gépeik rosszabb minőségü párlatot állítanak elő, mint az általa használt saját készítésü lepárló berendezés. Tudomása szerint, ezek a személyek azért nem adják fel, mert a befektetett pénzösszeget, amit a készülékre költöttek, nem akarják kárba veszni.

\subsubsection{Magánfözéssel még foglalkozó személy interjúija}

A következö interjúalany 2010 óta foglalkozik magánfözéssel. Az anonimitást számára is biztositani kellett. Az interjú során 16 kérdést tettünk fel neki. Az interjúalany azért döntött az otthoni fözés mellett, mert korábban a bérfözés keretében elöállított pálinka mennyiségével és minőségével nem volt megelégedve, igy a bevezetett jogszabályváltozással lehetösége nyilt arra, hogy elsajátítsa az elméleti tudást és gyakorlati tapasztalatokat szerezzen ezen a téren. Egyrészt szabadidős tevékenységként kezdte el magánfözést, másrészt elmondása szerint mindig is érdeklödött ez iránt a téma iránt. Nem járt pálinkafözéssel kapcsolatos tanfolyamra, nem vett részt hasonló képzésen, viszont jövőbeli teveiben szerepel egy hivatalos papír megszerzése. Internetröl, ismerősöktől tanulta meg a tevékenységet. Jelenleg egy gyárilag vásárolt egylépcsős fözökészüléke van. Nem bízik az otthon készitett lepárló berendezésekben, ezért döntött úgy, nagyobb értékben vásárol egy biztonságosabb készüléket. A beszélgetés során megemlítettük neki, hogy sok bérfözető azon a véleményen van, miszerint ezek a gépek robbanásveszélyesek. Meglátása szerint nem jelent kockázatot, ha megfelelö odafigyeléssel, és hozzáértéssel kezelik. Hallott ő is arról az esetröl, mikor felrobbant valaki berendezése, de véleménye szerint a figyelmetlenség okozta.

Rákérdeztünk, hogy milyen gyümölcsökböl állított már elö pálinkát. Számára az a fontos, hogy minél jobb, aromásabb párlatot kapjon, így sokféle gyümölccsel próbálkozott. Már fözött szilvát, szölöt, törkölyt, körtét, barackot, kökényt, birsalmát, almát, csipkebogyót, meggyet. Meggyőződése, hogy egy otthoni készüléken is lehet ugyanolyan minőségü pálinkát lefözni, sőt akár jobbat is, viszont ennek elengedhetetlen feltétele a szakmai tudás. Álláspontja szerint, jobban megéri, ha otthon föz, ugyanis kisebb üstje van, mint az átlag bérfözdékben, így kisebb mennyiséget tud kifözni, valamint nem kell más cefréjével összeönteni. Időnként volt rá példa, hogy költségesebb volt az előállítás, mintha kivitte volna a szeszfözdébe, ellenben ez nem volt számára befolyásoló tényezö. Az interjúalany a 2010-ben bevezetett jogszabályt teljes mértékben pozitivnak véli, és a jövöben is otthon kívánja kifözni cefréjét. Elmondta viszont, hogy tart attól, hogy ebben a 
formában nem maradnak szabályok (2014 szeptember). Ha a jövőben a magánfözöket is ellenörzés alá vonják, nem hagyna fel a tevékenységgel, és saját készülékét bejelentené a NAV-hoz. Elmondása szerint a befektetett pénzbeli ráforditások túl magasak ahhoz, hogy egyszerüen felhagyjon vele. Végezetül megkérdeztük, hogy véleménye szerint a pálinkafözés szakmának minősül-e. Egyes esetekben a pálinkafözést szakmának nevezné, ahol olyan méretü és pontosságú lepárló-készülékek vannak, amelyekhez magas szintü hozzáértés szükséges.

\section{5. Összegzés}

Az eddigi kutatásunk során kapott információkból azt a következtetést vonhatjuk le, hogy a jogszabályváltozások következtében pozitívumok és negatívumok is megállapíthatók. A hipotézisek vizsgálata:

1.) A korábbi évekhez viszonyitva a jó minőségü gyümölcsből készült pálinka elöállítása iránti kedv tradicionálisan megváltozott a 0 forintos adótétel figyelembevételével. Tehát ez a megállapítás igaznak minősült.

2.) Negatívumként tudjuk megállapítani, hogy a magánszeszfözdékben alkalmazott szeszföző berendezések, és az azokon elöállított pálinka költsége magas, és nem minden esetben elégítik ki a fözők által elvárt minőségnek. Ezen kívül számszeri adatokat nem tudunk felmutatni amellett a megállapitás mellett, hogy az otthoni pálinkafözö készülékek száma milyen mértékben nött meg, mivel erröl hivatalos nyilvántartás még nincsen (2014 szeptember).

3.) A szakmai tudás, a magas költségek és a nem megfelelő minőségü pálinka miatt az otthonfözetök kedve alábbhagyott. Ez a feltételezésünk beigazolódott.

4.) A bérfőzetők nem fözetnék ki cefréjüket, ha az meghaladná a 43 hlf-ot, és utána adót kellene fizetni. Ez a hipotézisünk nem igazolódott be teljes mértéig, ugyanis a válaszadók csupán $51 \%$-a nem fözetné ki a fent említett esetben a cefréjét, a megkérdezettek $49 \%$-a viszont igen.

5.) A következö hipotézisünk, miszerint a bérszeszfözde szolgáltatását leginkább az idősebb, 45 év feletti bérfözetők veszik igénybe, beigazolódott. A megkérdezettek 73\%-a tartozott ebbe a korosztályba.

\section{Irodalomjegyzék}

Balázs G. (1998): A magyar pálinka. Aula Kiadó, Budapest.

Balázs G. (2004): Pálinka a hungarikum. Állami Nyomda Rt. Kiadó, Budapest.

Békési Z., Csarnai E. (2010): Házi pálinkafözés. Mezögazda Kiadó, Budapest.

Békési Z., Pándi F. (2005): Pálinkafözés. Mezőgazda Kiadó, Budapest.

Gál J. (2003): A környezeti piac közép- és kelet-európai trendjei. Disszertáció $/ \mathrm{PhD} / \mathrm{BMGE}$, Budapest.

Gál J. (2008): A vöröshagyma vizsgálatának néhány érdekessége és hatása Makóra. 50. Jubileumi Georgikon Napok Konferencia, Keszthely, 2008.09.25-26. konferencia cd

Horváth Gy. (2004): A kérdöives módszer. Müszaki könyvkiadó, Budapest. 
Illés S. (2007) Polgármesteri szemmel a turizmusról és a migrációról. Comitatus, 17 (10), 50-66. net.jogtar.hu <http://net.jogtar.hu/jr/gen/hjegy_doc.cgi?docid=A0300127.TV> (2014.09.10.) net.jogtar.hu <http://net.jogtar.hu/jr/gen/hjegy_doc.cgi?docid=A0400008.PM> (2014.09.10.) Panyik G.-né (2013): Agyas pálinka és likör készitése. Cser Kiadó, Budapest.

Szabó S.-né (2012): Gyümölcspálinka-fözés. FVM Vidékfejlesztési és Szaktanácsadási Intézet, Budapest. 